\section{Association between order of birth and chronic malnutrition of children: a study of nationally representative Bangladeshi sample}

\author{
Associação entre ordem de nascimento e \\ desnutrição crônica em crianças: estudo de uma \\ amostra nacional representativa em Bangladesh \\ Asociación entre el orden de nacimiento y la
desnutrición crónica infantil: un estudio de una
muestra representativa Bangladesí a nivel nacional
}

Mosfequr Rahman 1

\begin{abstract}
This paper examines the net effect of birth order on child nutritional status in Bangladesh using data from the Bangladesh Demographic Health Survey, 2011 (BDHS). Analyses were restricted to 4,120 surviving, lastborn singleton children who were younger than 36 months at the time of the survey. Logistic regression was used to assess the association between birth order and child nutritional status. Results indicate $38.1 \%$ children are stunted and $8.2 \%$ children are fifth or higher order birth. Order of birth is one of the significant predictors of child being stunted. Third order, fourth order, and fifth or higher order children are $24 \%, 30 \%$, and $72 \%$, respectively, more likely to be stunted after adjusting for all other variables. Besides birth order, results also indicate that child age, size at birth, birth intention, maternal education, maternal body mass index, wealth index, place of residence and mass media access exert strong influences over child malnutrition. Reducing birth rates which limit number of births and birth order as well may reduce child malnutrition in Bangladesh.
\end{abstract}

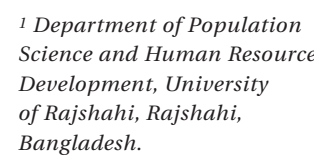

1 Department of Population Science and Human Resource Development, University of Rajshahi, Rajshahi, Bangladesh. 


\section{Introduction}

Child stunting, defined as decelerated or arrested growth, is associated with higher morbidity and mortality, shorter height in adulthood, lower educational achievement and reduced productivity in adulthood. Therefore, child growth patterns are strong predictors of future human capital and social progress and of the health of future generations 1,2 . Stunting is a good indicator of long-term malnutrition. Wasting and underweight have distinct etiologies and are not good measurements of long-term morbidity and malnutrition 3,4,5. Stunted children are at greater risk of impaired cognitive development and reduced neuromotor functioning, factors that contribute to poor academic performance and reduced work productivity in adulthood 3,6,7. The main factors of children being stunted include poor living conditions, household food insecurity, low parental education, lack of access to quality health and unhealthy living environments.

Globally, an estimated 165 million or $26 \%$ of children under the age of five are stunted; 52 million or $8 \%$ are wasted; and 100 million or $16 \%$ are underweight ${ }^{8}$. Malnutrition accounts for $35-45 \%$ of worldwide deaths among children less than five years old 9,10. However, Bangladesh has one of the highest rates of child malnutrition in the world 11, which represents the leading cause of child morbidity and mortality in the country 12. Two out of every five children in Bangladesh suffer from moderate-to-severe underweight 13 , and roughly two thirds of deaths among children younger than five years were attributed to undernutrition 14 . Therefore, there is a need to focus on priorities, actions and strategies to combat the enduring problem of child undernutrition worldwide.

Parental decisions have a profound effect on a child's development. Allocation of household resources has a direct impact on child's health and consequently affect the productivity of the children when they are grown up and their life expectancy increases 15. According to Sulloway 16, differential parental investment motivates differences in the strategies that children in the same family use to solicit parental investment. Other than the economic point of view of birth order, a broad range of studies have dealt with the impact of birth order on child mortality 17,18 , children's education 19,20, childhood type 1 diabetes 21,22 , childhood asthma, allergy and eczema ${ }^{23}$. These studies demonstrated that the effects of birth order have some variances in individual differences. The Bangladesh Demographic Health Survey (BDHS) 2011 report showed that unwanted birth and child mortality increases with higher birth order 24. The report also showed that antenatal care and postnatal care from a medicallytrained provider as well as postnatal checkup for children and full vaccination decline rapidly with higher order of birth 24 . Therefore, a parent's feelings towards a later born and unwanted child might have an adverse impact on the child's health when these feelings contribute to conscious or unconscious neglect of the index child, resulting in inadequate nutrition, lack of parental bonding, and inattention to healthcare needs. The literatures above suggest that higher birth order might have an impact on child nutrition. Therefore, it is important to study the association between birth order and child nutritional status. To the author's knowledge, no study has been conducted in recent times which assesses the association between birth order and child nutrition. Considering its importance, therefore, this study examines the effect of birth order on child malnutrition and hypothesizes that higher order birth will be more likely to be associated with stunting than lower order birth.

\section{Methods}

\section{Sample}

This study analyzed data from the 2011 BDHS, a nationally representative sample of women of childbearing age, which was carried out between July and December 2011 in collaboration with the National Institute for Population Research and Training. A two-stage, stratified cluster sample of 600 primary sampling units was constructed (207 in urban areas and 393 in rural areas) 24 . The primary sampling units were derived from the 2011 Bangladesh Population and Housing Census. A total of 18,222 eligible women aged 12-49 were identified to participate in the survey, 17,842 were interviewed, for a response rate of $98 \%$. The principal reason for non-response among eligible women was their absence from home despite repeated visits to the household.

The BDHS data collection procedures received ethical approval from the Institutional Review Board of Macro International in Calverton, United States of America, and from the National Ethical Review Committees in Bangladesh. Five well-designed, pre-tested questionnaires (a Household Questionnaire, a Women's Questionnaire, a Men's Questionnaire, a Community Questionnaire, and a two Verbal Autopsy Questionnaire) were used during the survey. Questionnaires were drafted in English and then translated into Bangla, the national language of Bangladesh. The questionnaires were pre-tested 
on 100 households, 100 women, and 70 men in one urban and one rural cluster. Fieldwork for the 2011 BDHS was carried out by 16 interviewing teams, each consisting of one supervisor, one field editor, five female interviewers, two male interviewers, and one logistics staff member. Data collection was implemented in five phases, starting on July 8, 2011 and ending on December 27,2011 . The interviewers went to the respondents' houses and collected information from them by asking questions. Women from selected households were interviewed, whether literate or illiterate. Details of data collection and management procedure are described elsewhere 24 For this study, the data set was restricted to 4,120 surviving, last-born singleton children who were younger than 36 months at the time of the survey (Figure 1).

\section{Measures}

All variables were assessed via self-report. The birth order was categorized as first, second, third, fourth, and fifth and higher order of birth. Weight was measured using lightweight scales with digital screens, and the height/length boards were specially produced for use in survey settings 24 . The measured weights and heights of children were converted to weight-for-age and heightfor-age SD units (z-scores) using the WHO Child Growth Standards 25. These measures are routinely analyzed to provide assessment of child nutritional status 4 . To provide assessment of nutritional status, this study analyzed an anthropometric outcome variable: low height for age (stunting). Stunted children (chronically undernourished) were classified as such when their

Figure 1

Selection of the samples.

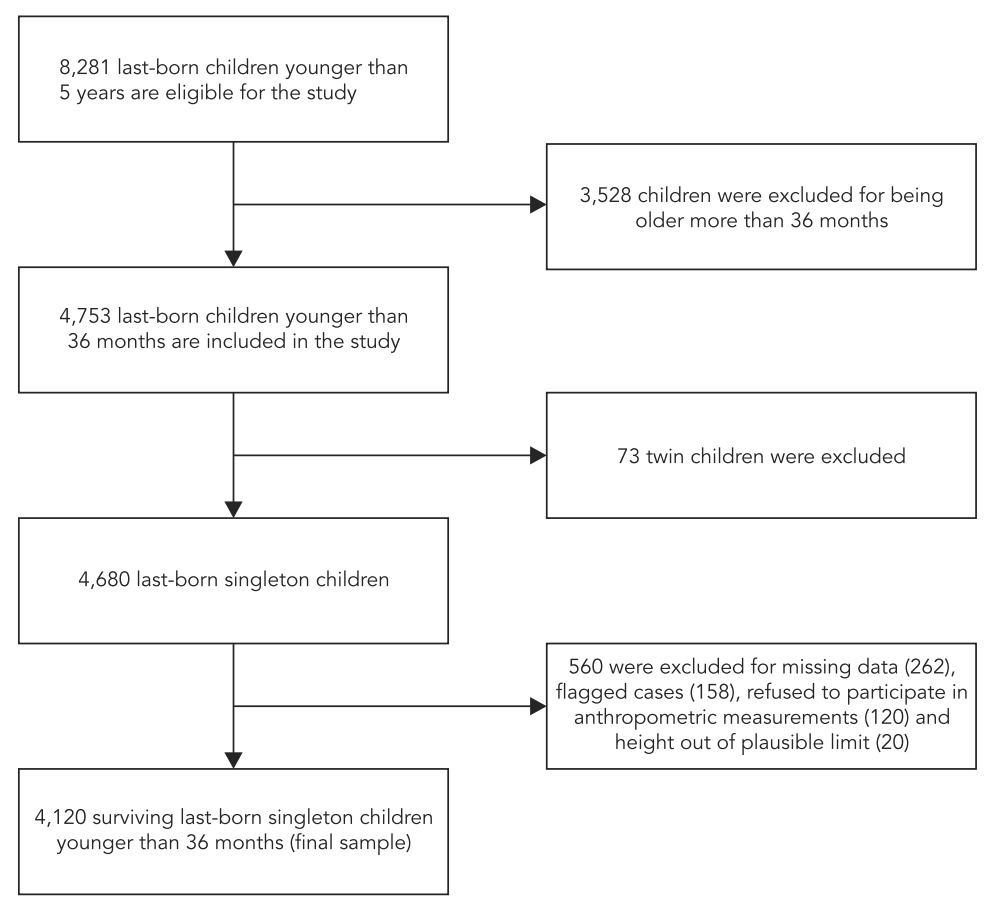


height-for-age z score was 2 standard deviations below the median of the World Health Organization's (WHO) reference population. Binary variables were created to define stunting: stunted or not stunted.

This study investigated whether the following socioeconomic and demographic characteristics of mothers and children were associated with the risk of stunting: the child's characteristics included child's age, gender, size at birth and last birth intention. Birth weight was not likely to be known for many babies, particularly for those born at home, therefore the mother's estimate of the baby's size was obtained in the BDHS 24. A mother's report of a child being "very small" or "smaller than average", even though subjective, is considered a useful proxy for low birth weight 24 . Birth intention was categorized as intended, mistimed and unwanted. "Intended" pregnancies were defined as those pregnancies to parent(s) who wanted the pregnancy, "unwanted" referred to pregnancies to parent(s) not wanting more children, and 'mistimed' were those pregnancies that were wanted, but at a later time. The questions and definitions used here are standard for reproductive health surveys worldwide 26 . Maternal characteristics included mother's age, educational level and maternal body mass index (BMI). Socioeconomic characteristics included rural or urban residence, media access and wealth index. The wealth index was constructed from data on household assets, including ownership of durable goods (such as a television, refrigerator, mobile phone, bicycle, etc.) and dwelling characteristics (such as source of drinking water, sanitation facilities, and construction materials). To create the wealth index, each asset was assigned a weight (factor score) generated through principal component analysis, and the resulting asset scores were standardized in relation to a normal distribution, with a mean of 0 and standard deviation of 127 . Each household was then assigned a score for each asset, and the scores were summed for each household; individuals were ranked according to the total score of the household in which they resided. The sample was then divided into quintiles with $1=$ poorest and $5=$ wealthiest $20 \%$ of households.

\section{Statistical analysis}

Bivariate analysis and multiple logistic regressions were used to investigate the relationship between order of birth and child malnutrition status, as well as a number of other sociodemographic variables. In all analyses, the significance level was set at p $<0.05$ (2-tailed). Unadjusted odds ratios were calculated to explore patterns among variables. Multiple logistic regressions were used to estimate the net effects of maternal pregnancy intention status on stunting by controlling for theoretically relevant variables. Three multivariate models were constructed for nutritional condition of children: stunting. In all three, multivariate logistic regressions were used: the first model examines the influence of order of birth on stunting, while controlling for the effects of the child's age, gender, size at birth and last birth intention. In model 2, maternal characteristics were added. Finally, in model 3, socioeconomic characteristics were added, and the effects of these were estimated. Odds ratios (OR) were estimated to assess the strength of the associations, and we used $95 \%$ confidence interval $(95 \% \mathrm{CI})$ for significance testing. All statistical analyses were conducted using IBM SPSS 20.0 for Windows (IBM Corp., Armonk, USA) to take into account sample weighting based on the complex design of the BDHS.

\section{Results}

Table 1 displays percentage distributions for the study variables of interest. On average, the study sample has $38.1 \%$ stunted children. Among the children $36.4 \%$ are first order birth, $29.2 \%$ were second order, $17.4 \%$ were third, $8.8 \%$ were fourth, and $8.2 \%$ are fifth and higher order birth. $17.7 \%$ children are born lower than average birth size $29.4 \%$ are either mistimed or unwanted birth. Mothers of more than half of children are young, aged $13-24$ years $(56.9 \%)$ and $17.1 \%$ have no education. $29.8 \%$ of mothers are thin (BMI $<18.5 \mathrm{~kg} /$ $\mathrm{m}^{2}$ ) and $10.2 \%$ are overweight-obese (BMI $\geq$ $\left.25.0 \mathrm{~kg} / \mathrm{m}^{2}\right) .77 .1 \%$ of the sample are from a rural background and $35.7 \%$ have no media access.

\section{Bivariate analysis}

Table 2 displays results from the bivariate analyses of malnourished children by order of birth and other variables of interest. Children of third order, fourth order, fifth and higher birth order are $19 \%, 36 \%$ and $78 \%$, respectively, more likely to be stunted than children of first order birth. Children, aged 12-23 months $(\mathrm{OR}=3.94$; 95\%CI: 3.34-4.64); lower than average birth size (OR = 1.79; 95\%CI: 1.52-2.10) and unwanted birth (OR = 1.32; 95\%CI: 1.09-1.60) are significantly more likely to be stunted. Children of mothers aged 35-49 years, thin and overweight-obese mothers, and those from rural areas are more likely to be stunted than young mothers (aged 13-24 years), normal BMI mothers and those from urban areas, respectively. Furthermore, maternal 
Table 1

Selected characteristics of last-born singleton children under 36 months from the Bangladesh Demographic Health Survey, 2011.

\begin{tabular}{|c|c|c|}
\hline Characteristics & $n(N=4,120)$ & $\%(95 \% \mathrm{Cl})$ \\
\hline \multicolumn{3}{|l|}{ Height for age } \\
\hline Not stunted (at or above -2SD) & 2,571 & $61.9(60.4-63.4)$ \\
\hline Stunted (from -2SD and below) & 1,549 & $38.1(36.6-39.6)$ \\
\hline \multicolumn{3}{|l|}{ Birth order } \\
\hline First order birth & 1,541 & $36.4(34.9-39.8)$ \\
\hline Second order birth & 1,208 & $29.2(27.8-30.6)$ \\
\hline Third order birth & 672 & $17.4(16.2-18.6)$ \\
\hline Fourth order birth & 363 & $8.8(7.9-9.7)$ \\
\hline Fifth and higher order birth & 336 & $8.2(7.4-9.1)$ \\
\hline \multicolumn{3}{|l|}{ Last-born child's characteristics } \\
\hline \multicolumn{3}{|l|}{ Child's age (months) } \\
\hline$<12$ & 1,455 & $35.9(34.4-37.4)$ \\
\hline $12-23$ & 1,404 & $34.0(32.5-35.4)$ \\
\hline 24-35 & 1,261 & \\
\hline \multicolumn{3}{|l|}{ Child gender } \\
\hline Male & 50.4 & $50.3(48.7-51.8)$ \\
\hline Female & 49.6 & $49.7(48.2-51.2)$ \\
\hline \multicolumn{3}{|l|}{ Size at birth } \\
\hline Average and higher & 3,387 & $82.3(81.1-83.4)$ \\
\hline Lower than average & 733 & $17.7(16.6-18.9)$ \\
\hline \multicolumn{3}{|l|}{ Last birth intention } \\
\hline Intended & 2,931 & $70.7(69.3-72.1)$ \\
\hline Mistimed & 680 & $16.3(15.1-17.4)$ \\
\hline Unwanted & 509 & $13.1(12.1-14.1)$ \\
\hline \multicolumn{3}{|l|}{ Mother's characteristics } \\
\hline \multicolumn{3}{|l|}{ Mother's age (years) } \\
\hline $13-24$ & 2,327 & $56.9(55.3-58.4)$ \\
\hline $25-34$ & 1,543 & $37.6(36.1-39.1)$ \\
\hline $35-49$ & 250 & $5.5(4.9-6.3)$ \\
\hline \multicolumn{3}{|l|}{ Mother's educational attainment } \\
\hline No education & 661 & $17.1(15.9-18.2)$ \\
\hline Primary education & 1,214 & $30.3(28.9-31.7)$ \\
\hline Secondary education & 1,889 & $45.3(43.8-46.9)$ \\
\hline Higher education & 356 & $7.3(6.6-8.2)$ \\
\hline \multicolumn{3}{|l|}{ Maternal BMI category * } \\
\hline Normal & 2,410 & $60.0(58.2-61.2)$ \\
\hline Thin & 1,231 & $29.8(28.3-31.1)$ \\
\hline Overweight-obese & 458 & $10.2(9.3-11.1)$ \\
\hline Data missing & 21 & \\
\hline \multicolumn{3}{|l|}{ Socioeconomic status indicators } \\
\hline \multicolumn{3}{|l|}{ Wealth index } \\
\hline Poorest & 877 & $22.8(21.6-24.2)$ \\
\hline Poorer & 776 & $19.9(18.7-21.1)$ \\
\hline Middle & 795 & $19.9(18.7-21.1)$ \\
\hline Richer & 824 & $19.3(18.1-20.5)$ \\
\hline Richest & 848 & $18.1(17.0-19.3)$ \\
\hline \multicolumn{3}{|l|}{ Area of residence } \\
\hline Urban & 1,317 & $22.9(21.7-24.2)$ \\
\hline Rural & 2,803 & $77.1(75.7-78.3)$ \\
\hline \multicolumn{3}{|l|}{ Media access } \\
\hline No media access & 1,408 & $35.7(34.2-37.1)$ \\
\hline Some media access & 2,708 & $64.3(62.8-65.7)$ \\
\hline Data missing & 4 & \\
\hline
\end{tabular}

95\% Cl: 95\% confidence interval; BMI: body mass index (defined as weight in kilograms divided by the square of height in meters); SD: standard deviaton.

* BMI categories were thin (<18.50), normal (18.50-24.99), or overweight-obese $(\geq 25.00)$.

Note: numbers are unweighted; percentages are weighted. 
Unadjusted odds ratios (OR) of stunting among last-born children less than 36 months from the Bangladesh Demographic Health Survey, 2011.

\begin{tabular}{|c|c|c|}
\hline Characteristics & Unadjusted OR (95\%Cl) & $\mathrm{p}$-value * \\
\hline \multicolumn{3}{|l|}{ Birth order } \\
\hline First order birth & 1.00 & \\
\hline Second order birth & $1.01(0.86-1.18)$ & 0.165 \\
\hline Third order birth & $1.19(1.01-1.41)$ & 0.045 \\
\hline Fourth order birth & $1.36(1.09-1.70)$ & 0.006 \\
\hline Fifth and higher order birth & $1.78(1.42-2.23)$ & 0.000 \\
\hline \multicolumn{3}{|l|}{ Last-born child's characteristics } \\
\hline \multicolumn{3}{|l|}{ Child's age (months) } \\
\hline$<12$ & 1.00 & \\
\hline $12-23$ & $3.94(3.34-4.64)$ & 0.000 \\
\hline $24-35$ & $1.71(1.49-1.96)$ & 0.000 \\
\hline \multicolumn{3}{|l|}{ Child gender } \\
\hline Male & 1.00 & \\
\hline Female & $1.01(0.88-1.14)$ & 0.258 \\
\hline \multicolumn{3}{|l|}{ Size at birth } \\
\hline Average and higher & 1.00 & \\
\hline Lower than average & $1.79(1.52-2.10)$ & 0.000 \\
\hline \multicolumn{3}{|l|}{ Last birth intention } \\
\hline Intended & 1.00 & \\
\hline Mistimed & $1.09(0.91-1.29)$ & 0.349 \\
\hline Unwanted & $1.32(1.09-1.60)$ & 0.004 \\
\hline \multicolumn{3}{|l|}{ Mother's characteristics } \\
\hline \multicolumn{3}{|l|}{ Mother's age (years) } \\
\hline $13-24$ & 1.00 & \\
\hline $25-34$ & $1.02(0.89-1.16)$ & 0.354 \\
\hline $35-49$ & $1.50(1.15-1.96)$ & 0.003 \\
\hline \multicolumn{3}{|c|}{ Mother's educational attainment } \\
\hline No education & 1.00 & \\
\hline Primary education & $0.82(0.68-0.98)$ & 0.032 \\
\hline Secondary education & $0.60(0.52-0.68)$ & 0.000 \\
\hline Higher education & $0.43(0.33-0.57)$ & 0.000 \\
\hline \multicolumn{3}{|l|}{ Maternal BMI category *夫 } \\
\hline Normal & 1.00 & \\
\hline Thin & $1.86(1.46-2.37)$ & 0.000 \\
\hline Overweight-obese & $2.90(2.25-3.73)$ & 0.000 \\
\hline \multicolumn{3}{|l|}{ Socioeconomic status indicator } \\
\hline \multicolumn{3}{|l|}{ Wealth index } \\
\hline Poorest & 1.00 & \\
\hline Poorer & $0.70(0.58-0.85)$ & 0.000 \\
\hline Middle & $0.69(0.58-0.82)$ & 0.000 \\
\hline Richer & $0.71(0.59-0.83)$ & 0.000 \\
\hline Richest & $0.48(0.40-0.58)$ & 0.000 \\
\hline \multicolumn{3}{|l|}{ Area of residence } \\
\hline Urban & 1.00 & \\
\hline Rural & $1.28(1.10-1.49)$ & 0.002 \\
\hline \multicolumn{3}{|l|}{ Media access } \\
\hline No media access & 1.00 & \\
\hline Some media access & $0.63(0.55-0.72)$ & 0.000 \\
\hline
\end{tabular}

95\% Cl: 95\% confidence interval; BMI: body mass index (defined as weight in kilograms divided by the square of height in meters).

* $\mathrm{p}$-values refer to the differences between groups;

** BMI categories were thin (<18.50), normal (18.50-24.99), or overweight-obese $(\geq 25.00)$.

Note: measures are weighted. 
education, household wealth and maternal access to media are also significantly negatively associated with children being stunted.

\section{Multivariate analysis}

Results from Table 3 indicate that birth order is a significant predictor of a child being stunted in Bangladesh as it is significant in all the models. Children of third order, fourth order, fifth and higher order birth are $24 \%, 30 \%$ and $72 \%$, respectively, significantly more likely to be stunted than children of first order birth after controlling for all other variables (model 3).The results also indicate that children aged 12-23 months (OR = 4.23; 95\%CI: 3.61-5.10) and 24-35 months (OR = 1.84; 95\%CI: 1.59-2.13) are more likely to be stunted than children aged under 12 months. A child whose size at birth is lower than average and is unwanted is 1.81 times and 1.13 times, respectively, more likely to be stunted than children whose size at birth is average and higher, and children who were intended. Children of mothers with a secondary education and higher education are $19 \%$ and $25 \%$, respectively, less likely to be stunted. It is also noticeable that children of thin mothers are $29 \%$ more likely to be stunted but children of overweight-obese mothers are $43 \%$ less likely to be stunted than normal BMI mothers. Furthermore, children from richest household are $39 \%$ less likely to be stunted than poorest household.

\section{Discussion}

This study supports the hypothesis and suggests that higher birth order increases the likelihood of being stunted of a child despite the influences of other children, and of maternal and socioeconomic variables. Over the last few decades, though the birth rate has declined rapidly in Bangladesh, still families have more than two children on average (2.3 children per woman) 24 , especially in rural areas. Moreover, Bangladesh has one of the highest rates of child malnutrition in the world 11. Therefore, understanding the relationship between birth order and child nutrition is particularly important for Bangladesh, where a higher number of children is still considered as a higher means of income. This study provides important insights into the relationship between order of birth and chronic nutritional status of children under three years of age. Specifically, this study finds that higher birth order has a strong connection with child malnutrition after controlling for other theoretically relevant variables suggesting that a mother having fewer children is a determining factor for child nutrition which in turn produces healthy future generations and reduces child mortality in Bangladesh. A possible explanation for this association could be that higher order births are more likely to be unwanted which results in less attention and care from parents: antenatal and postnatal care and child checkup decreases with the higher birth order 24 . Another explanation could be that intra-household allocation of food and resources decreases with an increasing number of births in the household 16. As a result, births of higher order might suffer from various health hazards as well as malnutrition. This finding is consistent with previous studies while assessing child nutritional status by birth order as a confounding factor in Bangladesh 28 and in other countries $26,29,30$. Therefore, the present finding suggests that the efforts of lowering birth order as well as birth rates in Bangladesh may not only reduce child malnutrition but also improve maternal and child health outcomes, and provide the nation a healthy future generation.

As well as birth order, a number of other characteristics of the child and mother, as well as socioeconomic characteristics have a strong influence on child malnutrition status in Bangladesh. The child's age is an important factor associated with the risk of stunting. This corroborates with earlier findings 31,32 , and results also suggest that children aged 12-23 months have the highest level risk for stunting than those under 12 months. In the third year of life, with their introduction to the family diet, children become more responsible for feeding themselves which may contribute to inadequate energy and protein intake. Not surprisingly, a child's size at birth appears to be an important indicator of the child's malnutrition. This present study indicates that children with lower than average birth size were significantly more likely to be stunted. Consistent with previous studies 26,29 , this study also reveals that maternal birth intention appears to be an important predictor of a child being stunted. These observed associations can be explained by the effects of a mother not wanting her child and their care giving behavior towards such children. The mother's feelings contribute to conscious or unconscious negligence of the index child and may reduce a mother's ability to cope with the everyday needs of a small child and diminish the quality of care giving behaviors, leading to negative health consequences for children 33 .

This study includes several maternal characteristicswhile assessingtherelationshipbetween birth order and the child being stunted. Consistent with previous studies in Bangladesh 34,35, 
Multivariate adjusted odds ratios (OR) of stunting and birth order of last-born children less than 36 months from the Bangladesh Demographic Health Survey, 2011.

\begin{tabular}{|c|c|c|c|}
\hline \multirow[t]{3}{*}{ Characteristics } & \multicolumn{3}{|c|}{ Stunting } \\
\hline & First * & Second $\star \star$ & Third *** \\
\hline & Adjusted OR (95\%Cl) & Adjusted OR (95\%Cl) & Adjusted OR (95\%Cl) \\
\hline \multicolumn{4}{|l|}{ Birth order } \\
\hline First order birth & 1.00 & 1.00 & 1.00 \\
\hline Second order birth & $1.01(0.85-1.19)$ & $1.09(0.91-1.30)$ & $1.06(0.88-1.27)$ \\
\hline Third order birth & $1.22 \#(1.01-1.47)$ & $1.30 \#(1.05-1.60)$ & $1.24 \#(1.01-1.54)$ \\
\hline Fourth order birth & $1.42 \# \#(1.11-1.82)$ & $1.38 \#(1.05-1.81)$ & $1.30 \#(1.08-1.71)$ \\
\hline Fifth and higher order birth & 1.88 \#\#\# (1.46-2.42) & 1.84 \#\#\# (1.37-2.47) & 1.72 \#\#\# (1.27-2.31) \\
\hline \multicolumn{4}{|l|}{ Last-born child's characteristics } \\
\hline \multicolumn{4}{|l|}{ Child's age (months) } \\
\hline$<12$ & 1.00 & 1.00 & 1.00 \\
\hline $12-23$ & 4.12 \#\#\# (3.47-4.85) & $4.21 \# \# \#$ (3.55-4.99) & $4.29 \# \#$ (3.61-5.10) \\
\hline $24-35$ & 1.78 \#\#\# (1.52-2.02) & 1.85 \#\#\# (1.60-2.14) & 1.84 \#\#\# (1.59-2.13) \\
\hline \multicolumn{4}{|l|}{ Child gender } \\
\hline Male & 1.00 & 1.00 & 1.00 \\
\hline Female & $0.91(0.80-1.04)$ & $0.93(0.81-1.06)$ & $0.92(0.80-1.06)$ \\
\hline \multicolumn{4}{|l|}{ Size at birth } \\
\hline Average and higher & 1.00 & 1.00 & 1.00 \\
\hline Lower than average & 1.89 \#\#\# (1.59-2.25) & $1.82 \# \# \#(1.52-2.16)$ & $1.81 \# \# \#(1.52-2.16)$ \\
\hline \multicolumn{4}{|l|}{ Last birth intention } \\
\hline Intended & 1.00 & 1.00 & 1.00 \\
\hline Mistimed & $0.91(0.72-1.16)$ & $0.94(0.74-1.20)$ & $0.92(0.72-1.18)$ \\
\hline Unwanted & 1.23 \#\# (1.05-1.65) & $1.16 \# \#(1.05-1.56)$ & $1.13 \#(1.00-1.52)$ \\
\hline \multicolumn{4}{|l|}{ Mother's characteristics } \\
\hline \multicolumn{4}{|l|}{ Mother's age (years) } \\
\hline $13-24$ & NA & 1.00 & 1.00 \\
\hline $25-34$ & NA & 0.74 \#\# (0.61-0.89) & $0.79 \# \#(0.65-0.94)$ \\
\hline $35-49$ & NA & $0.84(0.60-1.17)$ & $0.89(0.63-1.25)$ \\
\hline \multicolumn{4}{|c|}{ Mother's educational attainment } \\
\hline No education & NA & 1.00 & 1.00 \\
\hline Primary education & NA & $0.89(0.72-1.10)$ & $0.98(0.79-1.22)$ \\
\hline Secondary education & NA & $0.72 \# \# \#(0.61-0.84)$ & $0.81 \# \#(0.65-0.96)$ \\
\hline Higher education & NA & $0.59 \# \#(0.44-0.80)$ & $0.75 \# \#(0.55-0.91)$ \\
\hline \multicolumn{4}{|l|}{ Maternal BMI category § } \\
\hline Normal & NA & 1.00 & 1.00 \\
\hline Thin & NA & $1.37 \# \#$ (1.18-1.59) & $1.29 \# \#(1.11-1.50)$ \\
\hline Overweight-obese & NA & 0.50 \#\#\# (0.39-0.65) & 0.57 \#\# (0.44-0.74) \\
\hline
\end{tabular}

(continues)

this study finds that maternal education plays an important role in assessing child malnutrition and suggests that greater maternal education leads to a decrease in the odds of child stunting. This study also found that children of ill-nourished mothers (i.e., those in the thin BMI category) are at higher risk of stunting than are children of well-nourished mothers. This is to be expected because ma- ternal nutritional status is a proximate determinant of the child's nutritional status 36 . The results of the study have shown that children in poorer households were at a much greater risk of being chronically under-nourished than children in better-off households 37 . These findings are consistent with an earlier Bangladeshi study 38 , where children from rural areas are significantly more likely to be stunted. 


\begin{tabular}{|c|c|c|c|}
\hline \multirow[t]{3}{*}{ Characteristics } & \multicolumn{3}{|c|}{ Stunting } \\
\hline & First * & Second $* \star$ & 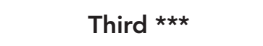 \\
\hline & Adjusted OR $(95 \% \mathrm{Cl})$ & Adjusted OR $(95 \% \mathrm{Cl})$ & Adjusted OR $(95 \% \mathrm{Cl})$ \\
\hline \multicolumn{4}{|c|}{ Socioeconomic status indicator } \\
\hline \multicolumn{4}{|c|}{ Wealth index } \\
\hline Poorest & NA & NA & 1.00 \\
\hline Poorer & NA & NA & $0.77 \#(0.63-0.95)$ \\
\hline Middle & NA & NA & $0.78 \#(0.64-0.94)$ \\
\hline Richer & NA & NA & $0.86(0.71-1.05)$ \\
\hline Richest & NA & NA & $0.61 \# \#$ (0.49-0.77) \\
\hline \multicolumn{4}{|l|}{ Area of residence } \\
\hline Urban & NA & NA & 1.00 \\
\hline Rural & NA & NA & $1.55 \#$ \# (1.29-1.98) \\
\hline \multicolumn{4}{|l|}{ Media access } \\
\hline No media access & NA & NA & 1.00 \\
\hline Some media access & NA & NA & $0.76 \#(0.52-0.95)$ \\
\hline
\end{tabular}

95\% Cl: 95\% confidence interval; BMI: body mass index (defined as weight in kilograms divided by the square of height in meters); NA: not applicable.

* The first logistic regression model considered only order of last birth and child's characteristics;

** The second model added mother's characteristics with the first model;

*** The third model added socioeconomic characteristics with the second model;

\# p-value < 10\%;

\#\# p-value $<5 \%$;

\#\#\# p-value < 1\%;

$\S$ BMI categories were thin (<18.50), normal (18.50-24.99), or overweight-obese $(\geq 25.00)$.

Note: measures are weighted.

Moreover, this finding also reveals that children of families who have some media access are less likely to be stunted.

Based on the above findings, this study therefore recommends that current policies towards improving maternal and child health care need to address higher birth order as an associated factor. Policy makers should pay particular attention to the factors that directly reduce fertility rates such as availability and effective use of contraception in Bangladesh. Reducing the number of malnourished children and fertility rates as well as improving the health of mothers and their children in Bangladesh will therefore need appropriate and effective policies and its proper implementation. These policies might include the efficient and effective use of contraceptives in order to reduce unwanted births and in turn reducing fertility rates. Family planning interventions should aim to reduce the number of extreme birth order pregnancies as well as provide increased support for mothers and infants to reduce malnutrition among children.

A few limitations to this study must be considered. This was a cross-sectional analysis exploring the association between higher birth orders and stunting prevalence. Thus, a causal association between the two factors cannot be established. Given that stunting reflects longterm cumulative nutritional status of individuals, it should be noted that this analysis was carried out based on the assumption that higher birth order is a good proxy for long-term high fertility rates. This study considered and discussed birth order as a health related variable, and ignored the economic point of view and intra-household resource distributions to births of a different order. Another limitation is that the selection of variables is constrained by the preexisting BDHS data, so this study was unable to include certain potentially important variables, including intrahousehold allocation of resources by different order of birth.

In conclusion, the findings from this study provide an important interaction between birth order and child malnutrition status in Bangladesh. This relationship is naturally complex, but results indicate a discernible effect of low birth order in reducing child malnutrition in Bangladesh. This finding may also be relevant in other developing countries where child malnutrition is common. However, future longitudinal studies are needed to investigate the influence of potential mechanisms mediating the association between birth order and poor child nutritional outcomes. 


\section{Acknowledgments}

The author is grateful to the MEASURE DHS for providing me with the data set. In addition, the author would like to acknowledge all individuals and institutions in Bangladesh involved in the implementation of the 2011 BDHS. The author is also thankful to Sonia Rahman for editing the English language of this manuscript.

\section{References}

1. Black RE, Allen LH, Bhutta ZA, Caulfield LE, Onis M, Ezzati M, et al. Maternal and child undernutrition: global and regional exposures and health consequences. Lancet 2008; 371:243-60.

2. Victora CG, Adair L, Fall C, Hallal PC, Martorell R, Richter L, et al. Maternal and child undernutrition: consequences for adult health and human capital. Lancet 2008; 371:340-57.

3. Onis M, Frongillo EA, Blössner M. Is malnutrition declining? An analysis of changes in levels of child malnutrition since 1980. Bull World Health Organ 2000; 78:1222-33.

4. World Health Organization. Physical status: the use of and interpretation of anthropometry. Geneva: World Health Organization; 1995.

5. Shrimpton R, Victora CG, Onis M, Lima RC, Blössner M, Clugston G. Worldwide timing of growth faltering: implications for nutritional interventions. Pediatrics 2001; 107:e75.

6. Berkman DS, Lescano AG, Gilman RH, Lopez SL, Black MM. Effects of stunting, diarrhoeal disease, and parasitic infection during infancy on cognition in late childhood: a follow-up study. Lancet 2002; 359:564-71.

7. Walker SP, Chang SM, Powell CA, Grantham-McGregor SM. Effects of early childhood psychosocial stimulation and nutritional supplementation on cognition and education in growth-stunted Jamaican children: prospective cohort study. Lancet 2005; 366:1804-7.
8. Children's Rights \& Emergency Relief Organization; World Bank. Levels \& trends in child malnutrition. Washington DC: Children's Rights \& Emergency Relief Organization/World Bank; 2012.

9. Black RE, Victora CG, Walker SP, Bhutta ZA, Christian P, Onis M, et al. Maternal and child undernutrition and overweight in low-income and middleincome countries. Lancet 2013; 382:427-51.

10. Liu L, Johnson HL, Cousens S, Perin J, Scott S, Lawn JE, et al. Global, regional, and national causes of child mortality: an updated systematic analysis for 2010 with time trends since 2000. Lancet 2012; 379:2151-61.

11. Helen Keller International Bangladesh. Household and community level determinants of malnutrition in Bangladesh. Dhaka: Helen Keller International Bangladesh; 2006.

12. Government of Bangladesh. Millennium development goals: Bangladesh progress report, 2007. Dhaka: Government of Bangladesh; 2007.

13. Children's Rights \& Emergency Relief Organization. The state of the world's children 2009: maternal and newborn health. Washington DC: Children's Rights \& Emergency Relief Organization; 2008.

14. World Bank. Repositioning nutrition as central to development: a strategy for large-scale action. Washington DC: World Bank; 2006. (Directions in Development). 
15. Rubalcava L, Contreras D. Does gender and birth order matter when parents specialize in child's nutrition? Evidence from Chile. J Appl Econ 2000; 3:353-86.

16. Sulloway FJ. Born to rebel: birth order, family dynamics, and creative lives. New York: Pantheon Books; 1996.

17. Rutstein SO. Infant and child mortality: levels trends and demographic differentials. Voorburg: WFS; 1984. (Comparative Studies. World Fertility Survey).

18. Shinwell E, Blickstein I, Lusky A, Reichman B. Effect of birth order on neonatal morbidity and mortality among very low birthweight twins: a population based study. Arch Dis Child Fetal Neonatal Ed 2004; 89:F145-8.

19. Black SE, Devereux PJ, Salvanes KG. The more the merrier? The effect of family size and birth order on children's education. Q J Econ 2005; 120: 669-700.

20. Ejrnæs M, Pörtner CC. Birth order and the intrahousehold allocation of time and education. Rev Econ Stat 2004; 86:1008-19.

21. Bingley PJ, Douek IF, Rogers CA, Gale EA. Influence of maternal age at delivery and birth order on risk of type 1 diabetes in childhood: prospective population based family study. BMJ 2000; 321:420-4.

22. Cardwell C, Carson D, Patterson C. Parental age at delivery, birth order, birth weight and gestational age are associated with the risk of childhood type 1 diabetes: a UK regional retrospective cohort study. Diabet Med 2005; 22:200-6.

23. Bernsen R, Jongste JC, Wouden JC. Birth order and sibship size as independent risk factors for asthma, allergy, and eczema. Pediatr Allergy Immunol 2003; 14:464-9.

24. National Institute of Population Research and Training, Mitra and Associates, ICF International. Bangladesh Demographic and Health Survey 2011. Dhaka: National Institute of Population Research and Training/Mitra and Associates/Calverton: ICF International; 2013.

25. WHO Multicentre Growth Reference Study Group. WHO child growth standards: length/height-forage, weight-for-age, weight-for-length, weightfor-height and body mass index-for-age. Methods and development. Geneva: World Health Organization; 2006.

26. Marston C, Cleland J. Do unintended pregnancies carried to term lead to adverse outcomes for mother and child? An assessment in five developing countries. Popul Stud (Camb) 2003; 57:77-93.
27. Gwatkin D, Rutstein S, Johnson K, Pande R, Wagstaff A. Socio-economic differences in health, nutrition and poverty. Washington DC: World Bank; 2000.

28. Khan REA, Raza MA. Nutritional status of children in Bangladesh: measuring composite index of anthropometric failure (CIAF) and its determinants. Pakistan Journal of Commerce and Social Sciences 2014; 8:11-23.

29. Shapiro-Mendoza C, Selwyn BJ, Smith DP, Sanderson M. Parental pregnancy intention and early childhood stunting: findings from Bolivia. Int J Epidemiol 2005; 34:387-96.

30. Ukwuani FA, Suchindran CM. Implications of women's work for child nutritional status in subSaharan Africa: a case study of Nigeria. Soc Sci Med 2003; 56:2109-21.

31. Omilola B. Patterns and trends of child and maternal nutrition inequalities in Nigeria. Washington DC: International Food Policy Research Institute; 2010. (IFPRI Discussion Paper).

32. Pongou R, Ezzati M, Salomon JA. Household and community socioeconomic and environmental determinants of child nutritional status in Cameroon. BMC Public Health 2006; 6:98.

33. Ammaniti M, Ambruzzi AM, Lucarelli L, Cimino S, D’Olimpio F. Malnutrition and dysfunctional mother-child feeding interactions: clinical assessment and research implications. J Am Coll Nutr 2004; 23:259-71.

34. Frost MB, Forste R, Haas DW. Maternal education and child nutritional status in Bolivia: finding the links. Soc Sci Med 2005; 60:395-407.

35. Semba RD, de Pee S, Sun K, Sari M, Akhter N, Bloem MW. Effect of parental formal education on risk of child stunting in Indonesia and Bangladesh: a cross-sectional study. Lancet 2008; 371:322-8.

36. Channon AA. Can mothers judge the size of their newborn? Assessing the determinants of a mother's perception of a baby's size at birth. J Biosoc Sci 2011; 43:555-73.

37. Hong R, Banta JE, Betancourt JA. Relationship between household wealth inequality and chronic childhood under-nutrition in Bangladesh. Int J Equity Health 2006; 5:15.

38. van de Poel E, O'Donnell O, van Doorslaer E. Are urban children really healthier? Evidence from 47 developing countries. Soc Sci Med 2007; 65: 1986-2003. 


\section{Resumo}

O estudo analisa o efeito ajustado da ordem de nascimento sobre estado nutricional em crianças de Bangladesh, com base em dados do Inquérito Nacional de Demografia e Saúde daquele país (BDHS) em 2011. As análises se limitaram a 4.120 nascidos vivos de parto único, últimos na ordem de nascimento e vivos e com menos de 36 meses de idade no momento do inquérito. A regressão logística foi utilizada para avaliar a associação entre ordem de nascimento e estado nutricional. Segundo os resultados, 38,1\% das crianças apresentavam baixa estatura para a idade e $8,2 \%$ ocupavam quinto lugar ou mais na ordem de nascimento. A ordem de nascimento é preditor significativo de baixa estatura para a idade em crianças de Bangladesh. A terceira, quarta ou quinta posição ou mais na ordem de nascimento mostrou um aumento de probabilidade de $24 \%$, 30\% e $72 \%$, respectivamente, de baixa estatura para a idade, depois de ajustar para todas as outras variáveis. Além da ordem de nascimento, os resultados indicam que a idade da criança, comprimento cabeça-nádega ao nascer, intenção da gravidez, escolaridade materna, índice de massa corporal materna, índice de riqueza familiar, lugar de residência e acesso aos meios de comunicação de massa têm forte influência sobre a desnutrição infantil. A redução da taxa de natalidade e consequente limitação do número de nascimentos e da ordem de nascimento podem também reduzir a desnutrição infantil em Bangladesh.

Ordem de Nascimento; Desnutrição;

Estado Nutricional; Criança

\section{Resumen}

Este trabajo analiza el efecto neto del orden de nacimiento en el status nutricional infantil en Bangladés, utilizando datos de la Encuesta Demográfica Bangladesí sobre la Salud, 2011 (BDHS). Los análisis se restringieron a los últimos 4,120 bebés nacidos vivos, procedentes de un embarazo único, y que fueran menores de 36 meses en el momento de la realización de la encuesta. Se usó la regresión logística para evaluar la asociación entre el orden de nacimiento y el estado nutricional infantil. Los resultados indican que un $38.1 \%$ de los niños sufren retraso en su crecimiento y un $8.2 \%$ de los niños ocupan el quinto o un orden más elevado de nacimiento. El orden de nacimiento es uno de los predictores significativos del retraso en el crecimiento en los niños. Quienes ocupan el tercer, cuarto, quinto o puestos más elevados en este orden son niños que en un $24 \%, 30 \%$ y un $72 \%$, respectivamente, tienen más probabilidad de sufrir retraso en su crecimiento tras ajustar para todos otras variables. Asimismo, los resultados en el orden del nacimiento también indicaban que la edad y tamaño del niño tras el parto, así como el carácter del nacimiento, la educación materna, el índice de masa corporal materna, de riqueza, el lugar de residencia y el acceso a medios de comunicación ejercen fuertes influencias sobre la desnutrición infantil. Reduciendo la tasa de natalidad que limita el número de nacimientos y el orden de nacimientos se podría llegar a reducir la desnutrición infantil en Bangladés.

Orden de Nacimiento; Desnutrición Estado Nutricional; Niño
Submitted on $28 / \mathrm{Jan} / 2015$

Final version resubmitted on 19/Jun/2015 Approved on $01 / \mathrm{Jul} / 2015$ 